\title{
POLA ASUH ORANG TUA MILITER DALAM MENINGKATKAN KEMANDIRIAN ANAK
}

\author{
PARENTING PATTERNS OF THE MILITARY IN AN EFFORT TO \\ IMPROVE CHILDREN'S INDEPENDENCE
}

\author{
Alfina Bakti P*1, Ika Fitri Apriani² \\ ${ }^{1,2}$ Program Studi Pendidikan Guru Sekolah Dasar, Universitas Pendidikan Indonesia Kampus \\ Tasikmalaya, Indonesia \\ e-mail:*1alfinabaktip@upi.edu, 2ªpriani25@upi.edu
}

\begin{abstract}
Abstrak
Penelitian ini dilatarbelakangi oleh adanya asumsi mengenai orang tua siswa yang bertugas di bagian militer selalu menerapkan pola asuh otoriter kepada anak-anaknya dalam upaya membentuk karakter anak, khususnya dalam aspek kemandirian. Tujuan penelitian ini hadir untuk mengetahui pola asuh orang tua militer dalam upaya meningkatkan kemandirian anak. Penelitian ini menggunakan studi deskripstif dan subjek terdiri dari dua keluarga militer di Batalyon Artileri Medan 10. Hasil menunjukkan bahwa keluarga militer menerapkan pola asuh demokratis semi otoriter dalam upaya meningkatkan kemandirian anak. Pemodifikasian pola asuh otoriter dan demokratis yang diterapkan oleh kedua orang tua responden, dipengaruhi oleh latar belakang historis dan habits yang dimiliki berbeda. Terdapat beberapa hambatan penanaman pola asuh yang dialami kedua orang tua responden dalam upaya meningkatkan kemandirian anak, diantaranya sikap manja dan malas dalam diri anak, intensitas waktu yang dimiliki kedua serta miskomunikasi antara orang tua dan anak. Melalui pola asuh demokratis semi otoriter yang diterapkan kedua orang tua responden, memberikan dampak terhadap perkembangan kemandirian anak. Hal ini dibuktikan dengan tingkat kemandirian anak pada beberapa indikator, seperti percaya diri, mampu bekerja sendiri, menghargai waktu, bertanggung jawab, memiliki hasrat untuk maju, dan mampu mengambil keputusan sendiri, berada pada ranah yang baik.
\end{abstract}

Kata Kunci: pola asuh orang tua militer, kemandirian, kemandirian anak

\begin{abstract}
This study is held back by assumptions regarding the parents of the student serving in the military always applying authoritarian upbringing to his or her children in an effort to establish the character of the child, especially in an aspect of self-reliance. The purpose of this study was to learn about the upbringing of military parents in an effort to increase child independence. The study used a descriptive study and subject study made up of two military families in the 10th Field Artillery Battalion. Results suggest that military families adopt a semiauthoritarian upbringing in an effort to increase child independence. Modeling authoritarian and democratic fostering patterns imposed by both of the responsible parents, is affected by different historical backgrounds and habits. There are several obstacles to the development of a foster pattern that both parents experience in trying to increase the child's independence, including spoiled and lazy behavior in the child, a second intensity of time and miscommunication between parent and child. Through the semiauthoritarian upbringing adopted by both of the respondents' parents, affected the development of child independence. It is proven with the degree of child independence at some indicators, such as self-confidence, self-employment, respect time, responsibility, have a desire to advance, and be able to make decisions of its own, in a good realm.
\end{abstract}

Keywords: military parenting, independence, child self-reliance 


\section{PENDAHULUAN}

Pola asuh atau parenting merupakan cara orang tua berinteraksi dengan sang anak, cara orang tua berperilaku sebagai model di hadapan anak-anaknya, cara orang tua memberikan kasih sayang, menanggapi, dan membantu anak mengatasi masalahnya, hangat, terbuka, mau mendengarkan secara aktif dan realistic [1]. Berdasarkan pemaparan tersebut dapat diartikan bahwa pola asuh orang tua merupakan perlakuan orang tua terhadap anak dalam bentuk merawat, mengajar, mendidik, membimbing, melatih, yang terwujud dalam bentuk pendisiplinan, pemberian tauladan, kasih sayang, hukuman, ganjaran, dan kepemimpinan dalam keluarga melalui ucapan maupun tindakan-tindakan yang dilakukan oleh orang tua [1]. Pola asuh dalam keluarga memiliki peran penting dalam membantu perkembangan anak sebab didalamnya banyak terjadi interaksi maupun pengaruh budaya mendidik sehingga karakter anak akan terbentuk nantinya. Values yang ditanamkan oleh orang tua pada anak akan terinternalisasi sehingga anak mempunyai karakter yang hampir mirip dengan orang tua mereka.

Terdapat sejumlah hasil penelitian mengungkapkan bahwa pola asuh yang ditanamkan oleh orang tua kepada anaknya berpengaruh dalam membantu perkembangan kepribadian sang anak, salah satunya dalam aspek kemandirian. Pola asuh orang tua dan kemandirian anak memiliki hubungan yang positif dan signifikan [1]. Kemandirian merupakan aspek yang berkembang dalam setiap diri individu, yang bentuknya sangat beragam tergantung pada proses belajar dan proses perkembangan yang dialami setiap individu. Kemandirian diperoleh secara komulatif, dimana dalam proses menuju kemandirian, individu belajar untuk menghadapi berbagai situasi dalam lingkungan sosialnya sampai ia mampu berfikir dan mengambil tindakan yang tepat dalam mengatasi setiap situasi.

Pendidikan karakter menjadi sesuatu yang harus dibiasakan dan ditanamkan sejak kecil pada diri seseorang [2]. Ketepatan proses pembelajaran di sekolah akan mendukung siswa mengembangkan karakternya [3]. Selain itu, orang tua juga sangat berperan penting dalam perkembangan pribadi peserta didik karena peserta didik sebagian besar waktunya dihabiskan dalam lingkungan keluarga [4]. Setiap orang tua juga memiliki pola asuh yang berbeda-beda, mengikuti latar belakang yang dimilikinya dalam rangka membantu perkembangan kemandirian sang anak. Fokus pada orang tua yang berlatar belakang dari keluarga militer, asumsi awal penanaman pola asuh di dalam keluarga militer yang mayoritas menggunakan model pola asuh yang otoriter. Namun pada kenyataanya, tidak semua orang tua berlatar belakang militer menggunakan model tersebut. Hal tersebut terjadi karena adanya kombinasi pengasuhan antara ayah dan ibu. Aturan dalam keluarga militer dilakukan secara mufakat dan menunjukkan adanya kerja sama antara ayah dan ibu [5]. Pola asuh Ibu yang cenderung demokratis dan ayah yang cenderung otoriter, dipadukan oleh mereka dalam mendidik anak-anaknya.

Bertolak dari gagasan dan uraian di atas, penelitian ini bertujuan untuk mengetahui: 1) Jenis pola asuh yang digunakan oleh orang tua militer dalam upaya meningkatkan kemandirian anak, 2) Hambatan orang tua militer menanamkan pola asuh dalam upaya meningkatkan kemandirian anak, dan 3) Dampak pola asuh orang tua militer terhadap kemandirian anak.

\section{METODE PENELITIAN}

Pendekatan penelitian yang digunakan dalam penelitian ini adalah studi deskriptif kualitatif. Penelitian kualitatif menghasilkan dan mengolah data yang sifatnya deskriptif, seperti melalui wawancara, observasi, dan dokumentasi [5]. Penelitian dilakukan di Batalyon Artileri Medan 10, yang berlokasi di Jl. Cimandala Raya, Sukaraja, Bogor, Jawa Barat. Adapun subjek penelitian adalah yakni orang tua dari FRNH (anak A) dan orang tua NQS (anak B). Orang tua siswa tersebut kami wawancarai dan berikan angket. Adapun instrumen yang digunakan adalah angket dan pedoman wawancara. Ada enam indikator kemandirian yang kami teliti yaitu percaya diri, mampu bekerja sendiri, menghargai waktu, bertanggungjawab, memiliki hasrat untuk maju, dan mampu mengambil keputusan. 


\section{Hasil Penelitian}

\section{HASIL DAN PEMBAHASAN}

Hasil penilaian aktivitas kemandirian anak sebagai dampak dari pola asuh orang tua militer, melalui kegiatan observasi dan wawancara, dapat dideskripsikan pada tabel berikut ini:

Tabel 1. Hasil Penilaian Aktivitas Kemandirian Anak Sebagai Dampak Pola Asuh Orang Tua Militer

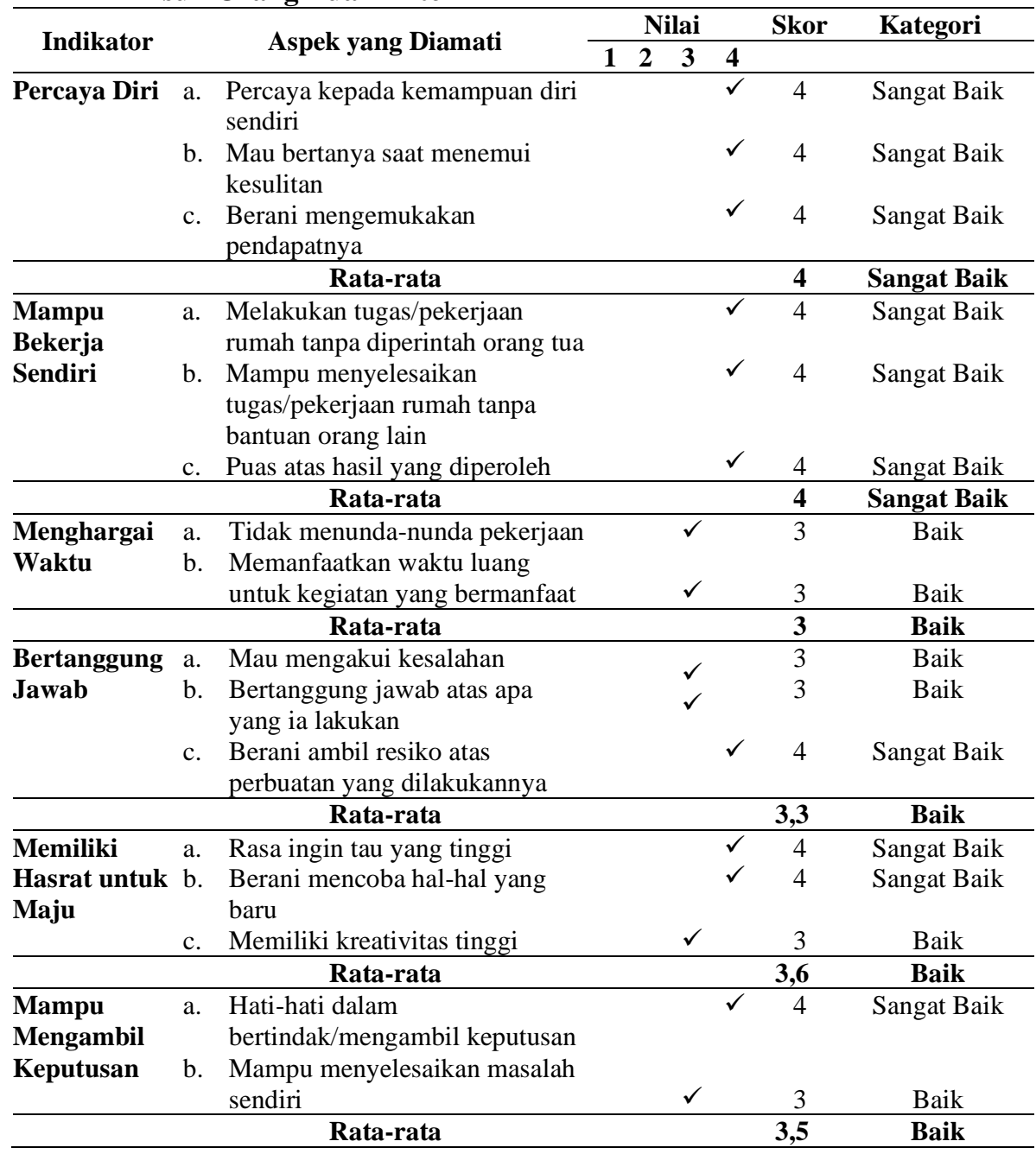

Kriteria penilaian: $1=$ Kurang, 2= Cukup, 3= Baik, 4= Sangat Baik

Pada indikator percaya diri yang terdiri dari aspek percaya kepada kemampuan diri sendiri, mau bertanya saat menemui kesulitan dan berani mengemukakan pendapatnya. Berdasarkan hasil penilaian dalam tabel menunjukkan skor yang diperoleh 4. Dengan demikian tingkat kemandirian anak pada indikator percaya diri berada pada kategori sangat baik. Seluruh aspek telah menunjukkan kategori yang sangat baik.

Pada indikator kedua, mampu bekerja sendiri yang terdiri dari aspek melakukan tugas/pekerjaan rumah tanpa diperitah orang tua, mampu menyelesaikan tugas/pekerjaan rumah tanpa bantuan orang lain dan puas atas hasil yang diperoleh. Berdasarkan hasil penilaian dalam tabel menunjukkan skor yang diperoleh 4. Dengan demikian tingkat kemandirian anak pada indikator mampu bekerja sendiri berada pada kategori sangat baik. Anak telah mampu memenuhi aspek-aspek yang terdapat di dalam indikator ini. 
Indikator ketiga menghargai waktu, yang terdiri dari aspek tidak menunda-nunda pekerjaan dan memanfaatkan waktu luang untuk kegiatan yang bermanfaat. Berdasarkan hasil penilaian dalam tabel menunjukkan skor yang diperoleh 3. Dengan demikian tingkat kemandirian anak pada indikator menghargai waktu berada pada kategori baik. Kedua aspek ini bisa menjadi perhatian bagi orang tua responden untuk ditingkatkan lagi agar sang anak menjadi lebih menghargai waktu nantinya.

Indikator keempat bertanggung jawab, yang terdiri dari aspek mau mengakui kesalahan, bertanggung jawab atas apa yang ia lakukan dan berani ambil resiko atas perbuatan yang dilakukannya. Berdasarkan hasil penilaian dalam tabel menunjukkan skor yang diperoleh 3,3. Dengan demikian tingkat kemandirian anak pada indikator bertanggung jawab berada pada kategori baik. Pada aspek berani ambil resiko atas perbuatan yang dilakukan telah berada pada kategori sangat baik. Sedangkan dua aspek lainnya pada indikator ini berada pada kategori baik. Kedepannya orang tua bisa meningkatkan lagi kedua aspek tersebut agar rasa tanggung jawab dalam diri sang anak menjadi lebih baik lagi.

Indikator kelima memiliki hasrat untuk maju, terdiri dari rasa ingin tahu yang tinggi, berani mencoba hal-hal yang baru dan memiliki kreativitas yang tinggi. Berdasarkan hasil penilaian dalam tabel menunjukkan skor yang diperoleh 3,67. Dengan demikian tingkat kemandirian anak pada indikator memiliki hasrat untuk maju berada pada kategori baik. Pada indikator ini, aspek memiliki kreativitas yang tinggi berada pada kategori baik dibandingkan dua aspek lainnya. Hal ini bisa menjadi perhatian bagi orang tua untuk memberikan pengasuhan bagi anak yang dapat meningkatkan kreativitas dalam diri anak.

Indikator terakhir mampu mengambil keputusan, yang terdiri dari hati-hati dalam bertindak/mengambil keputusan dan mampu menyelesaikan masalah sendiri. Berdasarkan hasil penilaian dalam tabel menunjukkan skor yang diperoleh 3,5. Dengan demikian tingkat kemandirian anak pada indikator ini berada pada kategori baik. Kedepannya orang tua bisa memberikan pengasuhan kepada anak mengenai bagaimana cara menyelesaikan permasalahan sendiri, agar kemampuan sang anak pada aspek ini menjadi lebih meningkat.

Berdasarkan data diatas dapat disimpulkan bahwa indikator-indikator yang menunjukkan tingkat kemandirian anak sebagai dampak pola asuh orang tua militer, sudah berada pada ranah yang baik. Anak telah mampu menghargai waktu, dibuktikan dengan mereka bangun jam 5 pagi untuk melaksanakan ibadah sholat dan persiapan ke sekolah. Anak mampu bekerja sendiri, ketika membereskan kamar tidurnya setelah dipakai. Anak juga memiliki kepercayaan diri, dengan berani mengutarakan apa yang ingin disampaikan kepada kedua orang tuanya. Selanjutnya anak memiliki hasrat untuk maju, dapat ditunjukkan ketika mereka selalu ingin mencoba hal-hal yang baru. Dan juga anak mampu mengambil keputusan, hal ini dibuktikan dengan mereka selalu berfikir dua kali jika ingin berbuat sesuatu. Terakhir anak mampu bertanggung jawab, ditunjukkan ketika berbuat kesalahan mereka akan mengakuinya dan langsung meminta maaf.

\section{Pembahasan}

Berdasarkan hasil wawancara dan observasi yang dilakukan oleh penulis kepada dua orang responden, yakni orang tua dari FRNH (anak A) dan orang tua NQS (anak B). Dari temuan di lapangan, kedua orang tua responden menggunakan pola asuh demokratis semi otoriter dalam upaya meningkatkan kemandirian anak,.

\section{Pola Asuh Orang Tua Militer dalam Upaya Meningkatkan Kemandirian Anak}

Pola asuh yang diterapkan oleh orang tua kepada anaknya dilatarbelakangi oleh historis atau pengalaman yang dimilikinya. Setiap keluarga biasanya memiliki pola asuh yang berbeda-beda terhadap anak-anaknya. Ada keluarga yang hanya menggunakan satu jenis pola asuh, dan ada pula orang tua yang memodifikasi pola asuh tersebut untuk diterapkan kepada anak-anaknya. Salah satu modifikasi pola asuh yang cukup banyak digunakan, terutama oleh orang tua militer yakni pola asuh demokratis semi otoriter. Pola asuh demokratis semi otoriter adalah penggabungan antara pola asuh demokratis dan otoriter.

Pemodifikasian pola asuh tersebut disebabkan habitus dan latar belakang yang dimiliki oleh suami dan sang istri yang berbeda, sehingga menciptakan praktik sosial berupa pemilihan pola 
asuh yang berbeda juga [6]. Pola asuh otoriter ditandai dengan aturan sepenuhnya dari orang tua sedangkan anak hanya wajib mematuhinya [7]. Pola asuh demokratis ditandai dengan adanya diskusi antara orang tua dan anak, serta pola asuh ini mengutamakan aspek pendidikan dibandingkan aspek hukuman [7].

Pada dua keluarga yang menjadi informan dalam penelitian penulis, ditemukan bahwa kedua orang tua dari anak A dan anak B dalam meningkatkan kemandirian anaknya menggunakan pola asuh demokratis semi otoriter. Dimana pola asuh otoriter digunakan oleh pihak suami, dan pola asuh demokratis digunakan oleh pihak istri. Menurut pengakuan mereka, untuk menanamkan kemandirian dalam diri sang anak, pihak ayah lebih menggunakan cara yang tergolong keras dan mewajibkan anak untuk sangat disiplin dengan apa yang telah menjadi tanggung jawab mereka. Contohnya pada saat menghadapi anak yang melakukan kesalahan. Pihak ayah tidak akan segan menggunakan hukuman kepada anak supaya meninggalkan efek jera kepada diri sang anak. Hukuman tersebut dapat berupa; melakukan bersih-bersih rumah, melakukan penyitaan barang (seperti hp) yang dimiliki sang anak selama beberapa waktu, dilarang untuk bermain dalam jangka waktu yang ditentukan sang ayah, dan hukuman fisik (seperti push up dan lari). Itu semua dilakukan oleh sang ayah dengan alasan agar sang anak terbiasa disiplin sehingga nantinya akan berpengaruh pada kemandirian yang dimiliki dalam diri sang anak. Sedangkan dari pihak ibu lebih mempertimbangkan jenis kesalahan apa yang diperbuat anaknya dan lebih memilih untuk menasihati atau membicarakan secara baik-baik kepada anaknya.

Pola asuh otoriter lainnya yang diterapkan orang tua kepada sang anak yakni pada saat membiasakan anaknya melakukan kewajiban dan tugas yang dimilikinya dengan tepat waktu. Seperti pada saat melakukan ibadah sholat 5 waktu, mengerjakan pekerjaan sekolah, belajar, membantu pekerjaan rumah, bermain, dan ketika waktunya sang anak makan. Itu semua wajib dilakukan oleh sang anak tepat pada waktunya. Peringatan pertama akan diberikan oleh sang ayah jika anak tidak melaksanakan kewajibannya. Dan jika masih belum dilakukan juga pada waktu berikutnya, maka sang ayah akan langsung mengambil tindakan kepada anaknya tersebut.

Hal kontradiksi yang dilakukan oleh orang tua militer kepada anak adalah dalam hal memberikan kesempatan anak untuk menyatakan pendapatnya dan anak dibebaskan untuk mengambil keputusannya sendiri. Tentunya untuk melakukan hal tersebut, diperlukan komunikasi dua arah antara orang tua dan anak, sehingga tindakan atau keputusan yang akan diambil oleh sang anak tidak akan keluar dari batas yang seharusnya. Disini orang tua tidak boleh terlalu mengontrol apa yang ingin dilakukan oleh anaknya. Orang tua perlu memberikan sedikit kelonggaran agar sang anak tidak merasa tertekan dan terpaksa dalam melakukan apa yang ingin dilakukannya. Tindakan tersebut didukung oleh pola asuh yang dilakukan oleh sang ibu yakni pola asuh demokratis. Dalam hal ini orang tua berusaha menumbuhkan kontrol diri dalam diri anak tanpa terlepas dari kontrol orang tua.

Melalui pola asuh demokratis semi otoriter yang ditanamkan oleh orang tua kepada anaknya, orang tua dapat melakukan beberapa hal dalam upaya meningkatkan kemandirian sang anak. Pertama, orang tua dapat melakukan pembiasaan hal-hal yang baik kepada anak sedari kecil, seperti membiasakan anak membuang sampah pada tempatnya, membereskan mainan setelah dipakai, membereskan bekas makannya, serta membiasakan anak untuk membawa handuk saat pergi mandi. Bagi sebagian orang mungkin hal-hal tersebut dinilai sepele, tetapi jika hal-hal kecil seperti itu tidak dibiasakan oleh orang tua kepada anaknya sedari dini, maka nantinya perkembangan kemandirian sang anak akan terlambat dan sang anak akan menjadi pribadi yang bergantung dengan orang lain. Hal kedua yang perlu diperhatikan yakni kedisiplinan. Kedisiplinan erat kaitannya dengan kemandirian. Seseorang yang mandiri tentunya selalu menerapkan kedisiplinan dalam dirinya, seperti disiplin dalam waktu, disiplin tanggung jawab, disiplin aturan, dan lain-lainnya. Anak yang berada di keluarga militer, sangat ditekankan sekali oleh kedua orang tuanya dalam hal kedisiplinan. Tiada hari bagi mereka tanpa disiplin. Seperti yang dilakukan oleh orang tua anak A dan B, mereka sangat membiasakan anak-anaknya untuk disiplin, contohnya: membiasakan anak-anak mereka untuk bangun pukul 5 pagi melaksanakan ibadah sholat dan persiapan berangkat ke sekolah; ketika makan, anak harus tepat waktu dan tidak boleh berlama-lama menghabiskan waktunya untuk makan; waktunya anak belajar, maka anak 
Jurnal Ilmiah KONTEKSTUAL, Volume.3, No. 01, Agustus 2021, pp. 42-50

harus fokus belajar, tidak boleh ada bercanda, bermain hp saat belajar, apalagi dibarengi dengan menonton tv; dan ketika waktunya bermain, kedua anak tersebut dibiasakan oleh kedua orangtuanya untuk tahu waktu, tidak boleh bermain melebihi jam yang telah ditentukan oleh kedua orang tuanya. Disiplin terhadap waktu sangat-sangat ditekankan pada keluarga militer, salah satu contohnya anak dari keluarga militer dilarang keras oleh orang tuanya untuk bermain malam. Mayoritas orang tua militer memiliki jam malam tersendiri bagi anak-anaknya yang izin pergi untuk bermain. Contohnya, sang anak dilarang pergi atau bermain melebihi jam 9 malam. Anak diwajibkan sudah berada di rumahnya sebelum jam 9 malam. Sehubung penulis merupakan salah satu dari anak yang memiliki orang tua militer. Peraturan semacam ini pun masih diterapkan oleh orang tua penulis jikalau penulis sedang pergi atau bermain pada malam hari.

Komunikasi, merupakan hal ketiga yang perlu diperhatikan juga oleh orang tua militer kepada anaknya dalam upaya meningkatkan kemandirian anak. Dengan adanya komunikasi yang baik antara orang tua dan anak, maka kemandirian dalam diri sang anak sedikit-demi sedikit akan tumbuh [8]. Untuk mengajarkan hal kemandirian kepada anaknya, orang tua responden memberikan penjelasan mengenai kemandirian dengan bahasa yang sederhana dan mudah dipahami oleh anak-anaknya. Contohnya: dengan menjelaskan kepada mereka untuk membantu kedua orang tuanya ketika bersih-bersih rumah, jadi suatu ketika orang tua mereka sedang ada kegiatan dinas di batalyon, dan tidak sempat untuk beres-beres, maka sang anak bisa melakukannya walaupun hasilnya masih belum sempurna atau baik. Poin keempat, yang penting sekali dilakukan oleh orang tua militer dalam meningkatkan kemandirian anak adalah memberikan kepercayaan kepada sang anak. Dengan orang tua responden memberikan kepercayaan kepada anak-anaknya untuk membantu mengerjakan pekerjaan rumah, walaupun hasilnya masih belum sempurna, tetapi dengan diberikan kepercayaan untuk melakukan tugas tersebut sendiri, kedua anak responden akan merasa senang dalam mengerjakan pekerjaanya tersebut. Jika anak tidak merasa berat dengan apa yang ia lakukan, lama-kelamaan mereka akan terbiasa dan nantinya akan menjadi habits bagi diri mereka. Habits tersebut nantinya akan tumbuh menjadi kemandirian dalam diri sang anak.

Dari penjelasan tersebut, dapat dilihat bahwa dalam upaya meningkatkan kemandirian anak, orang tua militer tidak selamanya menggunakan pola asuh yang otoriter. Terjadi modifikasi pola asuh, antara pola asuh otoriter dengan pola asuh demokratis. Penggabungan kedua pola asuh tersebut terjadi karena perbedaan cara mengasuh anak dari pihak suami dan istri. Suami yang memiliki habiatus dan latar belakang militer, berkontradiksi dengan yang dimiliki sang istri, sehingga terciptanya pola asuh demokratis semi otoriter yang menjadi pilihan mereka dalam mengasuh anak.

\section{Hambatan Orang Tua Militer Menanamkan Pola Asuh dalam Upaya Meningkatkan Kemandirian Anak}

Dalam menanamkan pola asuh sebagai upaya meningkatkan kemandirian anak oleh orang tua responden, terdapat beberapa hambatan yang dialami mereka. Berikut adalah hambatan tersebut:

\section{a. Sikap Manja dan Malas Sesekali Masih Hadir Dalam Diri Anak}

Manja dan Malas merupakan sikap manusiawi yang terkadang masih hadir di dalam diri kita. Dari anak-anak hingga orang dewasa, sesekali masih melakukan sikap ini dalam dirinya. Sikap manja pada anak ditandai dengan selalu ingin diperhatikan dan depenuhi apapun kemauannya. Contohnya: ketika makan anak ingin disuapi, tidur masih ingin bersama dengan kedua orang tuanya, mandi masih ingin dimandikan, pakai baju masih ingin dipakaikan, dan lain sebagainya. Sedangkan sikap malas, ditandai ketika anak tidak ingin melakukan apa-apa atau menunda-nunda pekerjaan yang seharusnya ia lakukan.

Orang tua responden menjelaskan kepada penulis. Salah satu hambatan mereka menanamkan kemandirian dalam diri anaknya yakni, sikap manja dan malas yang sesekali masih hadir dalam diri anak A dan B. Menurut pemaparan orang tua anak A, salah satu contoh anaknya masih suka bersikap malas yaitu ketika mereka menyuruh sang anak untuk berhenti bermain handphone dan pergi untuk belajar. Dikarenakan waktu bermainnya telah habis dan 
harus lanjut untuk belajar, anak A terkadang menundanya dengan berkata "sebentar 5 menit lagi ya bu, nanggung nih soalnya lagi main game." Melihat hal tersebut, ayah dari Anak A biasanya langsung mengambil tindakan untuk menyita hpnya jikalau sang anak tidak disiplin dengan tanggung jawabnya tersebut. Sedangkan ibunya lebih memilih untuk memberi peringatan dan nasihat terlebih dahulu dibandingkan ayahnya yang langsung menyita hp tersebut tanpa banyak bicara. Hal tersebut dilakukan oleh orang tua anak A dengan alasan agar anaknya tidak kebiasaan untuk menunda-nunda pekerjaan.

Disisi lain, sikap manja yang menjadi hambatan dalam meningkatkan kemandirian dirasakan oleh orang tua anak B. Hal tersebut dibuktikan ketika anak B ingin diberikan perhatian lebih oleh kedua orang tuanya dibandingkan dengan saudara-saudaranya yang lain. Salah satu contohnya ketika sedang melakukan bersih-bersih rumah, anak B sesekali meminta kepada orang tuanya untuk tidak membantu bersih-bersih karena ia merasa bahwa dirinya masih terlalu kecil untuk melakukan pekerjaan tersebut. Tetapi orang tua dari anak B tidak membiarkan anaknya begitu saja untuk bermanja-manja. Orang tua anak B akan memberi penjelasan kepada anaknya bahwa ia harus ikut membantu melakukan pekerjaan tersebut, tidak boleh ada pembeda antara anak satu dan lainnya. Pekerjaan tersebut juga telah dibagi oleh orang tua anak B dengan menyesuaikan kemampuan yang dimiliki oleh setiap anaknya.

Sikap manja dan malas memang manusiawi masih suka hadir di dalam diri anak. Jangankan anak-anak, orang dewasa sekalipun masih suka melakukan sikap tersebut di dalam dirinya. Untuk menghadapi sikap manja dan malas yang ada dalam diri sang anak, orang tua harus tegas dan lebih disiplin kepada anaknya. Sehingga sikap manja dan malas tersebut nantinya tidak akan menjadi kebiasaan dalam diri sang anak.

\section{b. Waktu}

Hasil penelitian menemukan, hambatan kedua yang dirasakan oleh orang tua responden dalam menanamkan kemandirian anaknya adalah intensitas waktu yang dimiliki orang tua militer untuk berkomunikasi bersama keluarga sangat minim. Pihak ayah yang setiap harinya memiliki banyak kegiatan di batalyon, ditambah seringnya ayah melakukan Satuan Tugas (Satgas), seperti: satgas covid-19, satgas pemilu, satgas PAM di suatu wilayah pedalaman/perbatasan, dan lain-lain dengan jangka waktu yang cukup lama (minimal 2 bulan). Disisi lain, walaupun pihak ibu keluarga responden tidak bekerja (menjadi ibu rumah tangga sepenuhnya), tetapi dari batalyon juga sering mengadakan kegiatan-kegiatan bagi persitnya. Sedikit infomasi, Persit merupakan sebutan bagi istri tentara, dengan kepanjangan Persatuan Istri Tentara. Dan kebetulan, ibu dari kedua anak responden merupakan bagian dari pengurus Persit Batalyon Armed 10. Akan tetapi hambatan seperti ini masih bisa diatasi dengan cara mengkomunikasikan segala sesuatu dengan baik kepada sang anak. Orang tua sebisa mungkin menciptakan suasana yang harmonis di dalam keluarganya. Dengan hubungan yang harmonis di dalam keluarga, komunikasi akan berjalan dengan baik, orang tua pun sebisa mungkin akan meluangkan waktunya untuk melakukan pendekatan interpersonal kepada anaknya. Dengan begitu, orang tua pun masih tetap bisa menanamkan pola asuh kepada anak-anaknya sebagai upaya meningkatkan kemandirian.

\section{c. Miskomunikasi antara Orang Tua dan Anak}

Tak jarang anak-anak dari orang tua militer bisa dididik secara otoriter oleh orang tuanya. Sehingga sesekali ada masanya mereka merasa malas dan juga membangkang dengan pola asuh yang diterapkan kepadanya. Pola asuh ayah yang cukup keras dalam menerapkan kedisiplinan bagi anak-anaknya, sehingga berdampak pada timbulnya sikap malas dan pembangkang dalam diri sang anak. Dalam hal ini diperlukan komunikasi yang baik antara orang tua dan juga anak, sehingga tidak terjadi kesalahpahaman diantara anak maupun orang tua. Dengan adanya komunikasi yang baik, anak tidak akan salah paham dengan maksud orang tua menerapkan kedisiplinan tersebut kepada dirinya. Dan bagi orang tua, dapat mengerti cara mana yang lebih cocok digunakan kepada anaknya sebagai upaya meningkatkan kemandirian anak. 


\section{Dampak Pola Asuh Orang Tua Militer terhadap Kemandirian Anak}

Secara umum pola asuh dapat diartikan sebagai interaksi antara orang tua dan anak. Cara pengasuhan disini meliputi bagaimana orang tua bersikap dan berprilaku saat berhubungan dengan anak. Di dalam keluarga militer, pola asuh demokratis semi otoriter digunakan oleh orang tuanya untuk membentuk karakter anak-anak mereka, khususnya dalam membentuk kemandirian anak. Pola asuh yang digunakan oleh orang tua sangat berpengaruh terhadap perkembangan kemandirian anak [9]. Stimulus yang diberikan oleh orang tua kepada anaknya akan sangat mempengaruhi perkembangan kemandirian anak. Jika orang tua memberikan pola asuh dalam upaya meningkatkan kemandirian anak secara terus menerus, melalui latihan, pembiasaan, mencontohkan secara langsung maupun tidak, dan telah ditanamkannya sedari dini, maka kemandirian anak akan berkembang dengan baik.

Kemandirian adalah keadaan dimana individu mampu berdiri sendiri tanpa bergantung dengan orang lain. Individu yang mandiri ialah individu yang berani mengambil keputusan yang dilandasi oleh pemahaman akan segala konsekuensi dari tindakannya. Kemandirian merupakan kemampuan untuk mengendalikan dan mengatur, pikiran, perasaan, dan tindakan sendiri secara bebas, serta berusaha sendiri untuk mengatasi keragu-raguan yang ada di dalam dirinya [10]. Perkembangan kemandirian anak ditandai dengan mampu atau tidaknya menyelesaikan permasalahan yang mereka hadapi, menghargai waktu, bertanggung jawab, berani mengungkapkan pendapatnya, kreatif, serta mampu membuat keputusan-keputusannya sendiri. Seseorang yang mandiri memiliki ciri-ciri: 1) memiliki kepercayaan diri dalam melakukan tugastugasnya; 2) bertanggung jawab dengan apa yang dilakukannya; 3 ) memiliki hasrat untuk maju demi kebaikan dirinya sendiri; dan 4) mampu mengambil keputusan untuk masalah yang dihadapinya [10].

Berdasarkan penjelasan diatas, dapat disimpulkan bahwa seorang anak dikatakan telah memiliki kemandirian di dalam dirinya apabila memiliki ciri-ciri diantaranya: percaya diri dengan apa yang ia lakukan, mampu bekerja sendiri sesuai dengan kemampuannya, menghargai waktu, bertanggung jawab dengan apa yang dilakukannya, memiliki hasrat untuk maju demi kebaikan diri, serta mampu mengambil keputusan dalam mengatasi masalah yang dihadapinya.

\section{SIMPULAN}

Berdasarkan hasil penelitian dan pembahasan yang telah dilakukan mengenai pola asuh orang tua militer dalam upaya meningkatkan kemandirian anak, maka dapat disimpulkan bahwa: (1) pola asuh yang digunakan oleh orang tua militer kepada anaknya adalah pola asuh demokratis semi otoriter. Kedua orang tua responden memodifikasi dua jenis pola asuh tersebut untuk diterapkan kepada anak-anaknya. Pemodifikasian tersebut terjadi karena latar belakang historis serta habiatus yang dimiliki oleh pihak suami dan istri berbeda; (2) hambatan-hambatan yang ditemui orang tua militer dalam upaya meningkatkan kemandirian anak, umumnya disebabkan oleh sikap manja dan malas yang masih suka hadir dalam diri anak, kurangnya intensitas waktu dalam berkomunikasi antara orang tua dan anak sehingga masih suka terjadi miskomunikasi diantara keduanya; (3) upaya mengembangkan kemandirian anak sebagai dampak dari penanaman pola asuh demokratis semi otoriter oleh orang tua militer, menunjukkan bahwa tingkat kemandirian anak pada seluruh indikator berada pada kategori baik. Kedepannya orang tua militer bisa lebih memperhatikan beberapa aspek sikap kemandirian anak, agar perkembangan kemandirian dalam diri sang anak lebih meningkat.

\section{DAFTAR PUSTAKA}

[1] K. Sunarty, "Hubungan pola asuh orangtua dan kemandirian anak," Journal of Educational Science and Technology (EST), vol. 2, no. 3, pp. 152-160, 2016, [Online]. Available: https://ojs.unm.ac.id/JEST/article/view/3214.

[2] S. Mardikarini and L. C. K. Putri, "Pemantauan kedisiplinan siswa melalui 
penetapan indikator perilaku disiplin siswa kelas III," Jurnal Ilmiah KONTEKSTUAL, vol. 2, no. 1, pp. 30-37, 2020, [Online]. Available: http://jurnal.umus.ac.id/index.php/kontekstual/article/view/246.

[3] A. Purnomo, "Pemanfaatan komponen instrumen terpadu IPA Sekolah Dasar Negeri terakreditasi A," Jurnal Ilmiah KONTEKSTUAL, vol. 1, no. 1, pp. 7-17, 2019 , [Online]. Available: http://jurnal.umus.ac.id/index.php/kontekstual/article/view/53.

[4] M. Toharudin and A. Rukyat, "Model pendampingan belajar pada anak keluarga TKW di SD Negeri Wanacala 02 Brebes," Jurnal Ilmiah KONTEKSTUAL, vol. 2, no. 1 , pp. 50-56, 2020, [Online]. Available: http://jurnal.umus.ac.id/index.php/kontekstual/article/view/249.

[5] H. Herawati and A. Jalil, "Pola asuh anak di keluarga militer (TNI) di batalyon Arhanude 13 Kubang Pekan Baru," Jurnal Online Mahasiswa FISIP, vol. 2, no. 2, pp. $1-15, \quad 2015, \quad$ [Online]. Available: https://jom.unri.ac.id/index.php/JOMFSIP/article/view/7299.

[6] R. D. Setianing, "Pola asuh anak pada keluarga militer," Jurnal Mahasiswa Sosiologi, vol. 2, no. 1, 2015, [Online]. Available: http://jmsos.studentjournal.ub.ac.id/index.php/jmsos/article/view/81.

[7] A. Apriliana, "Studi deskriptif pola asuh orang tua Tentara Nasional Indonesia terhadap anak di tinjau dari segi nilai sosial di Batalyon Infanteri 403 Kompi Senapan C Demak Ijo," Repositori Universitas PGRI Yogyakarta, 2017, [Online]. Available: http://repository.upy.ac.id/1553/.

[8] K. Komala, "Mengenal dan mengembangkan kemandirian anak usia dini melalui pola asuh orang tua dan guru," Tunas Siliwangi, vol. 1, no. 1, pp. 31-45, 2015, [Online]. Available: http://e-journal.stkipsiliwangi.ac.id/index.php/tunassiliwangi/article/view/90.

[9] M. Lestari, "Hubungan pola asuh orang tua dengan kemandirian anak," Jurnal Pendidikan Anak, vol. 8, no. 1, pp. 84-90, 2019, [Online]. Available: https://journal.uny.ac.id/index.php/jpa/article/view/26777.

[10] F. Tresnningsih, D. P. D. Santi, and E. Sumiarsih, "Kemandirian belajar siswa kelas III SDN Karang Jalak I dalam pembelajaran tematik," Pedagogi: Jurnal Penelitian Pendidikan, vol. 6, no. 2, pp. 51-59, 2019, [Online]. Available: https://journal.uniku.ac.id/index.php/pedagogi/article/view/2407. 